\title{
PENGARUH PENAMBAHAN KARBON AKTIF DARI TANAH GAMBUT TERHADAP KAPASITANSI ELEKTRODA SUPERKAPASITOR BERBAHAN DASAR KARBON AKTIF CANGKANG KELAPA SAWIT
}

\section{THE EFFECT OF ADDITION OF ACTIVATED CARBONS FROM PEAT ON PERFORMANCE OF SUPERKAPASITOR BASE OF ACTIVATED CARBON OF PALM KERNEL SHELL}

\author{
Olly Norita Tetra ${ }^{1 *}$, Hermansyah Aziz ${ }^{1}$, Syukri $^{2}$, Bustanul Arifn ${ }^{3}$, Asih Novia $^{1}$ \\ ${ }^{1}$ Laboratorium Elektro/Fotokimia Jurusan Kimia, FMIPA, Universitas Andalas Padang 25163 \\ ${ }^{2}$ Laboratorium Kimia Material Jurusan Kimia, FMIPA, Universitas Andalas Padang 25163 \\ ${ }^{3}$ Laboratorium Kimia Organik Jurusan Kimia, FMIPA, Universitas Andalas Padang 25163 \\ *e-mail korespondensi: olly512@yahoo.com
}

\begin{abstract}
Abstrak
Pengaruh penambahan karbon aktif tanah gambut terhadap kinerja superkapasitor berbahan dasar cangkang kelapa sawit telah dipelajari. Karbon aktif dari tanah gambut dibuat dengan menambahkan KOH $10 \mathrm{M}$ dan dilakukan perendaman pada perbandingan massa 1 : 4 antara karbon dengan $\mathrm{KOH}$. Karbon aktif yang dihasilkan dikarakterisasi dengan XRD (X-Ray Difraksi), SEM-EDX (Scanning Elektron Microscopy-Energi Dispersive X - Ray), dan FTIR (Fourier Transform infrared Spektroscopy). Penambahan karbon aktif dari tanah gambut memberikan nilai kapasitansi meningkat menjadi 8063 kali lebih besar pada perbandingan masaa 1: 2 dengan luas luas pelat elektroda $3 \times 3 \mathrm{~cm}^{2}$, konsentrasi elektrolit $\mathrm{H}_{3} \mathrm{PO}_{4} 0,3 \mathrm{~N}$ dan waktu pengisian 15 menit. Pencampuran Karbon aktif dari tanah gambut dan cangkang kelapa sawit memiliki kinerja yang baik sebagai bahan elektroda superkapasitor.
\end{abstract}

Kata kunci: karbon aktif, cangkang kelapa sawit, tanah gambut, superkapasitor, kapasitansi

\begin{abstract}
The effect of the additions activated carbon of peat soils on the performance of superkapasitor based of palm kernel shell has been studied. Activated carbon from peat soil is done by adding $\mathrm{KOH} 10 \mathrm{M}$ and soaking at mass ratio of 1: 4 between carbon and $\mathrm{KOH}$. The resulting activated carbon is characterized by XRD (X-Ray Diffraction), SEM-EDX (Scanning Electron Microscopy-Energy Dispersive X-Ray), and FTIR (Fourier Transform Infrared Spectroscopy). The addition of activated carbon from peat soil gives the capacitance value increased to 8063 times at 1: 2 mass ratio with the plat area were of $3 \times 3 \mathrm{~cm}^{2}$, electrolyte concentration of $\mathrm{H}_{3} \mathrm{PO}_{4}$ 0,3 $\mathrm{N}$ and charging time 15 minutes. Mixing Activated carbon from peat soil and palm kernel shells has a good performance as a supercapacitor electrode material.
\end{abstract}

Keywords: activated carbon, palm kernel shell, peat soils, supercapacitor, capacitance

\section{PENDAHULUAN}

Superkapasitor atau yang dikenal sebagai kapasitor elektrokimia (EDLC, Electrochemically double-layer Capacitors) adalah lapisan rangkap listrik berupa elektroda yang dipisahkan oleh separator (Boyea, 2007). Bahan dasar elektroda yang biasa digunakan untuk superkapasitor adalah karbon aerogel (Nianping dkk, 2013), nanokomposit (Memoria, 2013), logam oksida (Ferreira dkk, 2014), dan polimer konduktif (Memoria, 2014). Namun kelangkaan dan mahalnya bahan tersebut menjadi faktor kendala dalam pembuatannya. Oleh sebab itu, dicari bahan dasar elektroda yang berasal dari bahan alam untuk mengurangi limbah supaya berbasis green chemistry. 
Pemakaian karbon yang merupakan material berpori sebagai elektroda telah banyak dimodifikasi untuk meningkatkan nilai kapasitansinya. Berbagai penelitian telah dilaporkan dengan memanfaatkan karbon dari bahan alam sebagai bahan elektroda, seperti limbah cangkang kelapa sawit (Hermansyah, 2016), biji karet (Olly dkk, 2015), sekam padi (Zhang dkk, 2017) dan daun teh (Chao dkk, 2013). Selain dari karbon aktif dilaporkan juga penggunaan membran keramik modifikasi dengan $\mathrm{TiO}_{2}$ sebagai bahan elektroda (Olly dkk, 2016).

Berdasarkan penelitian dari Chao Peng dkk (2013) dilaporkan bahwa penambahan karbon aktif dengan karbon aktif lain yang berbeda sumber biomassanya akan meningkatkan kemampuan dari superkapasitor dalam menyimpan muatan. Peranan perbandingan antara struktur mesopori dan mikropori akan memberikan peningkatan kapasitansi dari suatu elektroda (Chen-Hao dkk, 2016) Pemanfaatan karbon aktif dari limbah cangkang sawit telah pernah diteliti sifat-sifat listriknya dan menghasilkan nilai kapasitansi sebesar 41,21 $\mu \mathrm{F}$ (Hermansyah dkk, 2016). Nilai kapasitansi ini masih rendah, maka perlu dilakukan penelitian pencampuran karbon aktif dari cangkang sawit dan tanah gambut yang berfungsi sebagai bahan elektroda superkapasitor yang diharapkan dapat meningkatkan kinerja dari superkapasitor.

\section{METODE PENELITIAN}

\section{Alat dan Bahan}

Alat yang digunakan dalam penelitian ini adalah Furnace (Merck), hot plate (IKA' C-MAG HS 4), LCR-Meter (SANWA LCR700), XRD (PIXcel1D), SEM- EDX (S-3400N), FTIR (Shimadzu 8400), pH meter, ayakan $45 \mu \mathrm{m}$, peralatan gelas, lem fox, penjepit kertas, charger Handphone Nokia $(6,54 \mathrm{~V})$ bahan-bahan yang digunakan dalam penelitian ini yaitu sampel tanah gambut (diambil di Kambang Kabupaten Pesisir Selatan Sumatera Barat), cangkang kelapa sawit (diambil dari PT. AMP Plantation di Kabupaten Agam Sumatera Barat), larutan $\mathrm{H}_{3} \mathrm{PO}_{4}$ (Merck), KOH (Merck), PVA, $\mathrm{HCl}$, kertas batang padi dan akuades.

Preparasi karbon aktif cangkang kelapa sawit dan tanah gambut

Cangkang kelapa sawit dan tanah gambut masing-masing dikarbonisasi pada suhu $400^{\circ} \mathrm{C}$ selama 4 jam kemudian dihaluskan dan diayak dengan menggunakan ayakan berukuran $45 \mu \mathrm{m}$.

\section{Proses aktivasi}

Masing-masing karbon aktif dari tanah gambut dan cangkang kelapa sawit dilakukan perendaman dengan $\mathrm{KOH} 10 \mathrm{M}$ menggunakan perbandingan masa karbon dan $\mathrm{KOH}$ 1:4 dan didiamkan selama 4 jam. Karbon aktif difurnance pada suhu $400^{\circ} \mathrm{C}$ selama 4 jam. Selanjutnya dilakukan pencucian dengan menambahkan $\mathrm{HCl} 0,1 \mathrm{M}$ sampai $\mathrm{pH} 7$, dan dilanjutkan pencucian dengan akuades. Karbon aktif yang dihasilkan, dipanaskan pada suhu \pm $105^{\circ} \mathrm{C}$ (Chaitra dkk, 2016) (Hartono, Singgih \& Ratnawati, 2010).

\section{Karakterisasi karbon aktif cangkang kelapa sawit dan tanah gambut}

Karbon aktif cangkang kelapa sawit dan tanah gambut dikarakterisasi dengan menggunakan XRay Diffraction (XRD), Scanning Electron Microscopy-Energy Dispersive X-Ray (SEMEDX), dan FTIR (Fourier Transform Infrared Spektroscopy).

\section{Pembuatan elektrolit hidrogel polimer sebagai separator}

1 gram PVA dilarutkan dengan $10 \mathrm{~mL}$ larutan $\mathrm{H}_{3} \mathrm{PO}_{4}$ dengan konsentrasi $0,3 \mathrm{~N}$. Campuran tersebut dipanaskan pada suhu $45^{\circ} \mathrm{C}$ sampai homogen dan siap untuk dijadikan sebagai separator.

\section{Pembuatan plat elektroda superkapasitor}

Kertas batang padi dipotong dengan ukuran $3 \mathrm{x}$ $3 \mathrm{~cm} 2$ sebanyak 2 buah untuk masing-masing ukuran. Kertas batang padi tersebut ditimbang dan dicatat massanya. Masing-masing kertas batang padi dilapisi dengan campuran karbon aktif dari cangkang kelapa sawit dan tanah gambut dengan variasi perbandingan massa antara karbon aktif cangkang kelapa sawit dan tanah gambut $(0: 1,1: 0,1: 1,1: 2,1: 3,2: 1)$ yang dijadikan sebagai elektroda.

\section{Perakitan superkapasitor}

Rangkaian superkapasitor plat disusun seperti Gambar 1. Masing-masing kertas batang padi dilapisi dengan karbon aktif cangkang kelapa sawit yang dijadikan sebagai elektroda. Kedua elektroda disusun seperti sandwich yang dipisahkan oleh separator PVA (Polivinil Alkohol) di bagian tengahnya. Kedua plat elektroda diapit lempengan tembaga dan diapit oleh kaca. 


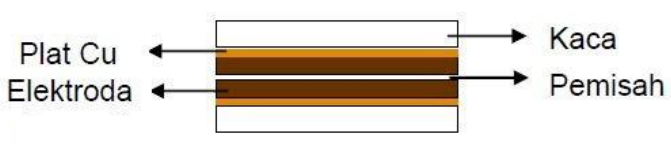

Gambar 1. Rangkaian Superkapasitor Metoda Plat / Sandwich

Pengukuran sifat listrik dari rangkaian superkapasitor

Pengukuran sifat listrik dilakukan dengan menggunakan LCR-Meter untuk mendapatkan nilai kapasitansi, Induktansi, dan Resistansi.

\section{HASIL DAN PEMBAHASAN}

\section{Karakterisasi karbon aktif}

\section{a. X-Ray Diffraction (XRD)}

Pola XRD pada tanah gambut menunjukkan puncak difraksi yang lebar pada $2 \theta=25^{\circ}$ dan $42^{\circ}$ menandakan bahwa karbon aktif tanah gambut bersifat amorf, karena struktur kristal biasanya memiliki banyak puncak yang energi yang tajam dan sempit sedangkan pada Gambar 2 tidak menunjukkan ciri-ciri tersebut (Guo dkk, 2007).

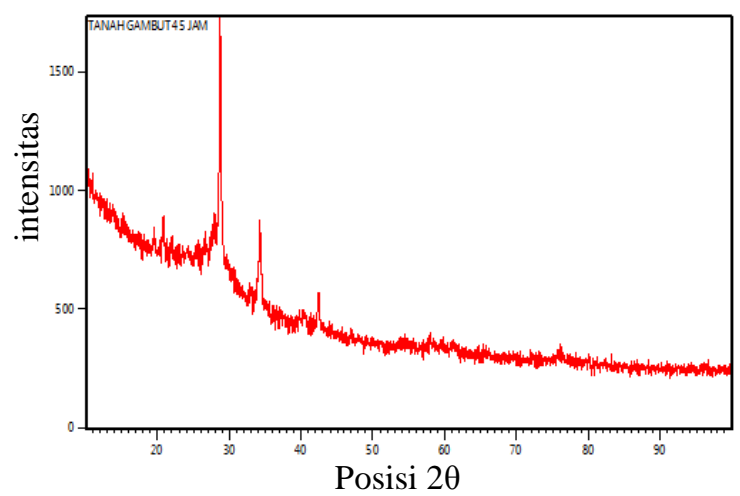

Gambar 2. Pola difraksi karbon aktif tanah gambut dengan suhu pembakaran $400^{\circ} \mathrm{C}$ selama 4 jam

Pola yang sama juga telah dilaporkan untuk karbon aktif tanah gambut yaitu puncak difraksi terletak pada $2 \theta$ yang berkisar pada $24^{\circ}-26^{\circ}$ dan $44^{\circ}$ (Tumirah dkk, 2015). Sehingga dapat dikatakan bahwa struktur tersebut adalah karbon. Berdasarkan hasil ini maka karbon aktif dari tanah gambut dapat digunakan sebagai bahan elektroda pada superkapasitor.

Pola yang sama untuk karbon aktif dari cangkang kelapa sawit juga dilaporkan pada jurnal Hermansyah aziz dkk (2016) seperti pada Gambar 3.

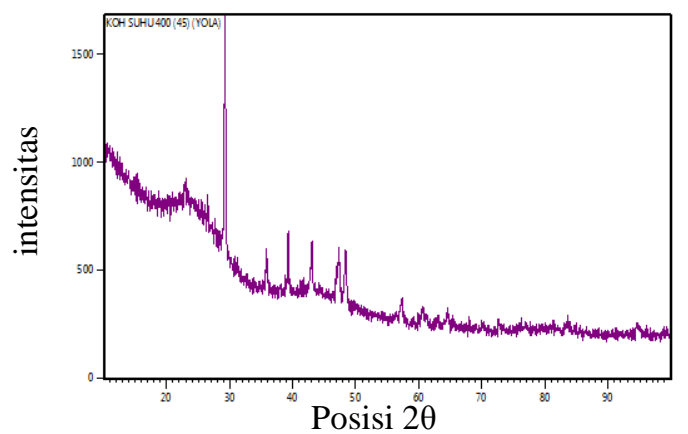

Gambar 3. Pola difraksi karbon aktif tanah gambut dengan suhu pembakaran $400^{\circ} \mathrm{C}$ selama 4 jam

\section{b. Fourier Transform Infrared Spectroscopy (FTIR)}

Gugus fungsi pada permukaan karbon aktif dipelajari menggunakan FTIR. Hasil uji FTIR tanah gambut didapatkan spektrum seperti pada Gambar 4.

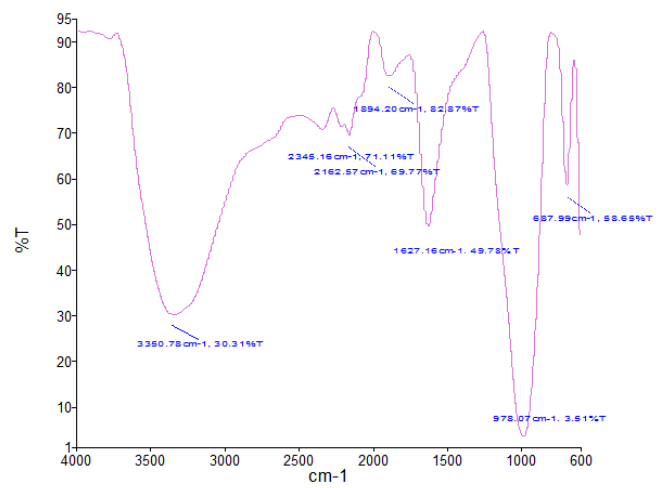

A.

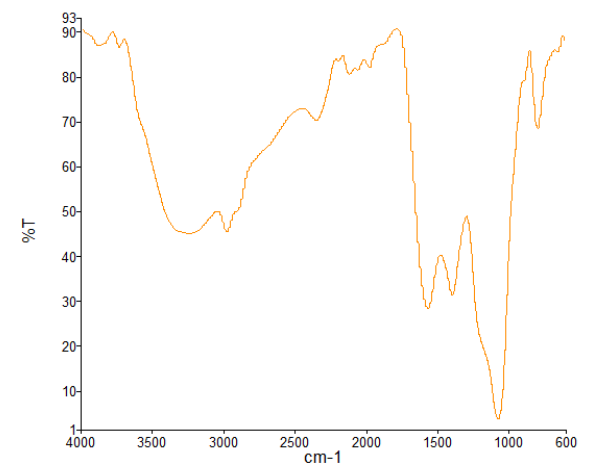

B.

Gambar 4. Spektrum FTIR (a) karbon tanah gambut (b) cangkang kelapa sawit

Gambar 4 (a) dan (b) pada semua spektrum menunjukkan adanya serapan pada angka gelombang 3350,78 cm daerah pita serapan dari gugus $\mathrm{O}-\mathrm{H}$ streching dari asam karboksilat, daerah 2162,57 $\mathrm{cm}^{-1}$ merupakan daerah pita serapan gugus $\mathrm{C}=\mathrm{C}$ 
streching, daerah 1672,16 $\mathrm{cm}^{-1}$ merupakan daerah pita serapan gugus $\mathrm{C}=\mathrm{C}$ streching senyawa aromatis, daerah 687,99 $\mathrm{cm}^{-1}$ merupakan daerah pita serapan ikatan $=\mathrm{C}-\mathrm{H}$. Banyaknya gugus fungsi pada karbon aktif tanah gambut dan cangkang kelapa sawit berperan dalam pembentukan lapis rangkanp listrik pada permukaan elektroda. Gugus fungsi yang hampir sama juga dilaporkan oleh Wan Azlina dkk.

\section{c. Scanning Electron Microscopy (SEM)}

Analisis SEM digunakan untuk melihat morfologi, homogenitas dan ukuran pori partikel dari karbon yang berasal dari cangkang kelapa sawit dan tanah gambut.

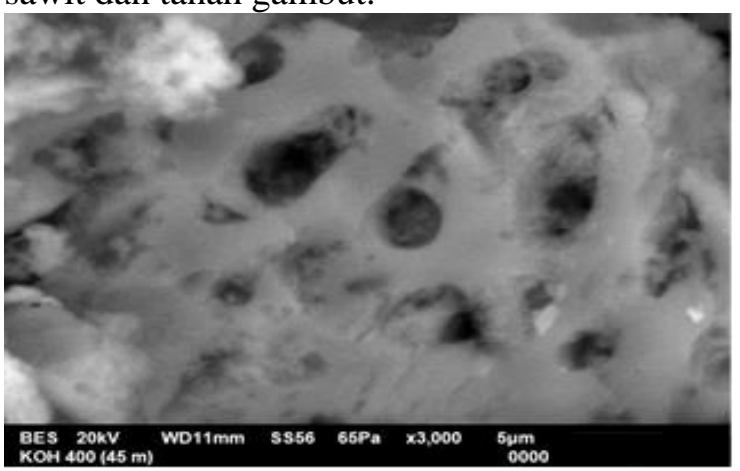

A.

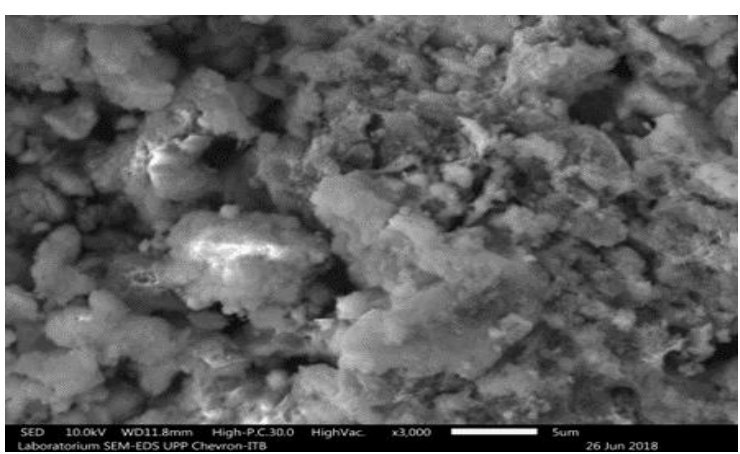

B.

Gambar 5. Hasil karakterisasi SEM dengan perbesaran 3000 kali pada (a) karbon aktif tanah gambut dan (b) karbon aktif cangkang kelapa

Pada Gambar 5(A) dapat dilihat bahwa morfologi permukaan karbon aktif cangkang kelapa sawit menunjukkan ukuran volume pori lebih besar dan distribusi ukuran pori lebih merata, dibandingkan dengan karbon aktif tanah gambut yang ukuran volume porinya lebih kecil (Gambar 5B). menurut Chen-hao dkk (2016) distribusi mesopori dan mikropori dapat meningkatkan nilai kapasitansi. Permukaan kedua karbon aktif berbentuk lubang-lubang yang didapatkan selama aktivasi berguna untuk adsorbsi ion dan menyimpan muatan.

\section{d. Energy Dispersive $X$-Ray $(E D X)$}

Analisis EDX terhadap karbon aktif dari tanah gambut menunjukkan komposisi material yang terdapat pada karbon aktif tersebut.

Tabel 1 Komposisi unsur karbon dari cangkang kelapa sawit dan tanah gambut

\begin{tabular}{ccc}
\hline \multirow{2}{*}{ Unsur } & \multicolumn{2}{c}{ Berat (\%) } \\
\cline { 2 - 3 } & $\begin{array}{c}\text { Cangkang } \\
\text { kelapa sawit }\end{array}$ & Tanah gambut \\
\hline C & 72,36 & 32,71 \\
O & 20,39 & 41,95 \\
Si & 0,26 & 15,32 \\
K & 6,99 & 10,02 \\
\hline
\end{tabular}

Berdasarkan Tabel 1 komposisi unsur karbon pada karbon aktif cangkang kelapa sawit $(72,36 \%)$ memiliki persentase yang lebih tinggi dibandingkan karbon aktif tanah gambut $(32,71 \%)$. Adanya perpaduan Karbon aktif ini memberikan kemampuan optimal dari karbon aktif dalam pembentukkan lapis rangkap listrik dipermukaan elektroda, sehingga akan memberikan nilai kapasitansi yang lebih tinggi.

Penelitian yang sama dilaporkan untuk pencampuran antara karbon aktif dari daun teh dengan karbon aktif daun teh jenis lainnya memberikan nilai kapasitansi yang lebih besar (Chao dkk, 2013).

\section{Pengaruh penambahan karbon aktif tanah gambut terhadap karbon aktif cangkang kelapa sawit}

Pengaruh penambahan karbon aktif tanah gambut terhadap karbon aktif cangkang sawit dengan perbandingan massa sebanyak 1:0, 1:1, 1:2, 1:3. Gambar 6 menunjukkan Nilai kapasitansi dari karbon aktif cangkang kelapa sawit sekitar 12,6976 $\mu \mathrm{F}$. pada saat ditambah karbon aktif tanah gambut nilai kapasitansinya semakin meningkat pada perbandingan 1:2 sekitar 1020,4 $\mu \mathrm{F}$ dan menurun pada perbandingan 1:3 sekitar 723,233 $\mu \mathrm{F}$. Hal ini disebabkan pencampuran struktur mesopori dari karbon aktif cangkang kelapa sawit dan struktur mikropori dari karbon aktif tanah gambut, dimana ukuran mesopori berperan sebagai penyimpan muatan sedangkan ukuran mikropori 
berperan sebagai menyebar muatan. Adanya variasi ukuran partikel maka nilai kapasitansinya lebih besar (Chen-Hao dkk, 2016).

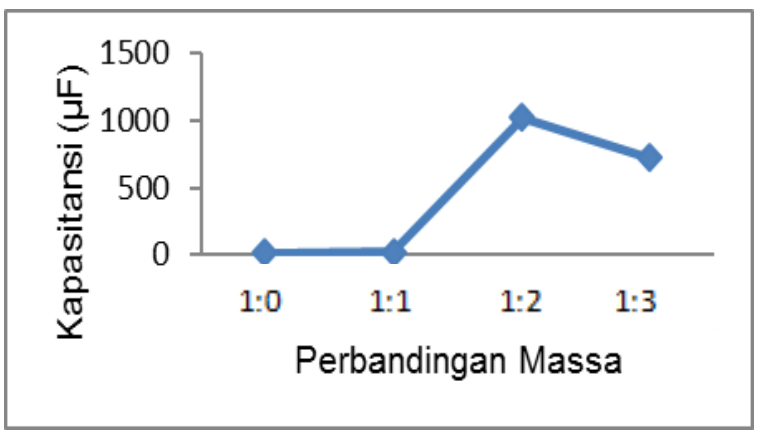

Gambar 6. Pengaruh penambahan karbon aktif tanah gambut terhadap karbon aktif cangkang kelapa sawit terhadap nilai kapaitansi elektroda

\section{Pengaruh penambahan karbon aktif cangkang kelapa sawit terhadap karbon aktif tanah gambut}

Pengaruh penambahan karbon aktif cangkang kelapa sawit terhadap karbon aktif tanah gambut dengan perbandingan massa sebanyak 1:0, 1:1, 1:2. Gambar 7 menunjukkan Semakin banyak cangkang sawit yang ditambahkan maka nilai kapasitansi yang didapatkan semakin kecil. Hal ini disebabkan karena tidak diimbanginya persentase antara karbon cangkang sawit dan tanah gambut yang didukung dengan hasil EDX sehingga penambahan karbon aktif cangkang kelapa sawit yang banyak tidak optimal membantu naiknya nilai kapasitansi dari superkapasitor.

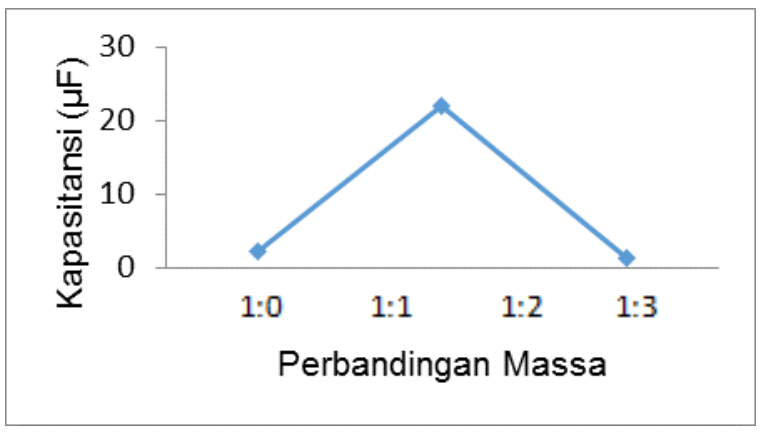

Gambar 7. Pengaruh penambahan karbon aktif cangkang kelapa sawit pada karbon aktif tanah gambut terhadap nilai kapasitansi elektroda

\section{KESIMPULAN}

Karbon aktif dari pencampuran tanah gambut dengan karbon aktif cangkang kelapa sawit memiliki performance yang baik sebagai bahan elektroda superkapasitor pada perbandingan 1:2. Dimana terjadi peningkatan kapasitansi dari elektroda superkapasitor sebesar 8036 kali lebih besar. Hal ini dikarenakan pencampuran dari struktur mesopori dan mikropori berdasarkan pada karaktersisasi XRD yang menyatakan karbon cangkang kelapa sawit adalah amorf berada pada $2 \theta$ yaitu berkisar 250 dan 420 dan hasil EDX didapatkan bahwa persentase karbon aktif cangkang kelapa sawit $72,36 \%$ sedangkan tanah gambut sekitar $32,71 \%$.

\section{DAFTAR RUJUKAN}

Boyea, J.M; R.E. Camacho; S. P. Turano; W. J. Ready. (2007). Carbon Nanotube-Based Supercapacitors: Technologies and Markets. Nanotechnology Law \&Business, 585 -593.

Chao, P., Xing-bin, Y., Ru-tao, W., Jun-wei, L., Yu-jing, O., Qun-ji, X., (2013). Promising Actived Carbons Derived From Waste TeaLeaves And Their Application In High Performance Supercapacitors Electrodes. Electrochimica Acta, 401-408.

Chaitra, K. Vinny, R. T. Sivaraman, P. Narendra Reddy. Chunyan, Hu. Krishna, Venkatesh. Vivek, C. S. Nagaraju, N. Kathyayini, N. (2016). Journal of Energy Chemistry, 6(28), 17.

Chen-Hao, Wang, Wei-Chen, Hsin-cheng, Hsu. Bing-Yuan, Yao. (2016). High Capacitance $\mathrm{KOH}$ Activated Nitrogen-Containing Porous Carbon Material From Waste Coffee Grounds In Supercapacitor. Advanced Powder Technology, 1387-1395.

Ferreira, C.S, Passos, R.R. Pocrifka, L.A. (2014). Synthesis and Properties of Ternary Mixture of Nikel/Cobalt/Tin Oxides for Supercapacitor. Power Sources, 271, 104107.

Guo, Yanping, David A. Rockstraw. (2007). Activated Carbons Prepared From Rice Hull By One-Step Phosphoric Acid Activation. Microporous and Mesoporous Materials,1219.

Hartono, Singgih, Ratnawati. (2010). Pembuatan Karbon Aktif dari Tempurung Kelapa Sawit dengan Metode Aktivasi Kimia. Jurnal Sains Materi Indonesia, 12 (1), 12-16.

Hermansyah, Aziz, Olly, N. T. Admin, A. Wahyu, R. (2016). Electrical Properties Of Supercapasitor Electrode Based On Activated 
Carbon From Waste Palm Kernel Shells. Der Pharma Chemica, 8, (15), 227-232.

Olly, N.T. Admin, A. Gesti, U. (2015). Pemanfaatan Limbah Tempurung Biji Karet Sebagai Bahan Elektroda Superkapasitor. Laporan Penelitian Dosen Muda, Universitas Andalas.

Olly, N.T, Hermansyah, A, Emriadi. (2016). Performance of $\mathrm{TiO}_{2}$-Carbon on Ceramic Template with Sodium Hydroxide Activation as Supercapasitors Electrode Materials. Der Pharma Chemica, 8 (17), 26-30.

Memori, R. Fery, I. Mikrajuddin, A. Khairurrijal. (2013) Synthesys and Characterization of Supercapacitor Using Nano-sized ZnO/Nanoporous Carbon Electrodes and PVA-based PolymerHydrogel Electrolytes. Materials Science Forum, 737, 191-196.

Memori, R. Fery, I. Mikrajuddin, A. Khairurrijal. (2014). Hydrogel-Polymer Electrolytes Based on Polyvinyl Alcohol and Hydroxyethylcellulose for Supercapacitor Applications. Electrochemical Science, 9, 4251-4256.
Soon, H.K. Eunji, L. Bum, S.K. Sang, G.K. Byung, J.L, Myung, S.K. Ji, C.J. (2014). Activated Carbon Aerogel as Electrode Material for Coin-Type EDLC Cell in Organic Electrolyte. Current Applied Physics, 14, 603-607.

Tumirah, Khadiran, Mohd, Zobir Huseein. Zulkarnain, Zainal. Rafeadah, Rusli. (2015). Textural and Chemical Properties of Activated Carbon Prepared from Tropical Peat Soil by Chemical Activation method. BioResources, 10 (1), 986- 1007.

Yacob, A. R. Majid, Z. A, Dewi, R. S. Inderan. (2008). Comparison of Various Source of High Surface Area Carbon Prepared by Different Type of Activation. The Malaysian Journal of Analytical Sciences. 12 (1), 264271.

Zhang, Wenli, Nan, Lin. Debo, Liu, Jinhui, Xu. Jinxin, Sha. Jian, Yin, Xiaobo, Tan. Huiping, Y. Haiyan, L. Haibo, Lin. (2007). Direct Carbonization Of Rice Husk To Prepare Porous Carbon For Supercapacitor Applications. Energy, 128, 618-625. 